\title{
Reversed dorsal metatarsal artery flap for reconstruction of a soft tissue defect of the big toe
}

\author{
Chenicheri Balakrishnan MD, Yeon-Jeen Chang MD, Anila Balakrishnan BS, Daniel Careaga MD
}

\begin{abstract}
C Balakrishnan, Y-J Chang, A Balakrishnan, D Careaga. Reversed dorsal metatarsal artery flap for reconstruction of a soft tissue defect of the big toe. Can J Plast Surg 2009;17(3):e11-e12.

Soft tissue defects of the great toe that include exposed tendon and bone present a reconstructive challenge for plastic surgeons. A distally based dorsalis pedis island flap based on the first dorsal metatarsal artery, which has been successfully used to cover the soft tissue defect following wide excision of melanoma of the big toe, is reported
\end{abstract}

Key Words: Dorsal metatarsal artery flap

D econstruction of the distal portion of the foot has always R represented a difficult problem in plastic surgery. A method for reconstruction of a soft tissue defect of the big toe using the reverse first dorsal metatarsal artery flap is presented. This flap is supplied by minute cutaneous branches of the first dorsal metatarsal artery and can be extended to the territory of the dorsalis pedis artery. A reversed dorsal metatarsal artery flap presents a viable alternative for reconstruction of soft tissue defects of dorsal great toe when local flap coverage is required.

\section{CASE PRESENTATION}

A 49-year-old man presented with a pigmented lesion over his big toe. An excision biopsy of the nail bed was carried out. The histology was negative for melanoma. He returned with a deformed nail and lesion at the tip of the toe a year later (Figure 1). A biopsy of this lesion revealed malignant melanoma with a thickness of $1.1 \mathrm{~mm}$. Metastatic work-up for melanoma was negative; therefore, a decision was made to undertake wide excision along with sentinel node biopsy.

A wide excision of the lesion was carried out leaving a defect of $4 \mathrm{~cm} \times 6 \mathrm{~cm}$ over the big toe. A reversed first dorsal metatarsal artery flap was elevated as a pedicle flap (Figures 2 and 3). The flap was transposed to the defect and the donor site was repaired using a full-thickness skin graft (Figure 4). At eighteen months the flap is stable and he is able to wear regular shoes (Figure 5).

\section{DISCUSSION}

Historically, options such as toe amputations, fillet flaps, cross leg flaps, reverse anterior artery flaps, and free autogenous and allogenic tissue transfers have been used. But despite their successes, each of these are associated with significant difficulties. For example, the use of the fillet flap precludes toe salvage. The cross leg flap requires two operative stages, causing discomfort and stiffness to immobile joints. The reverse anterior tibial flap

\section{Un lambeau renversé de l'artère métatarsienne dorsale pour reconstruire une anomalie des tissus mous du gros orteil}

Les anomalies des tissus mous du gros orteil qui incluent l'exposition du tendon et de l'os posent un défi de reconstruction pour le plasticien. On présente l'installation d'un lambeau distal en îlot de la région dorsale du pied à l'aide de la première artère métatarsienne dorsale, utilisé avec succès pour recouvrir l'anomalie des tissus mous après la large excision d'un mélanome du gros orteil.

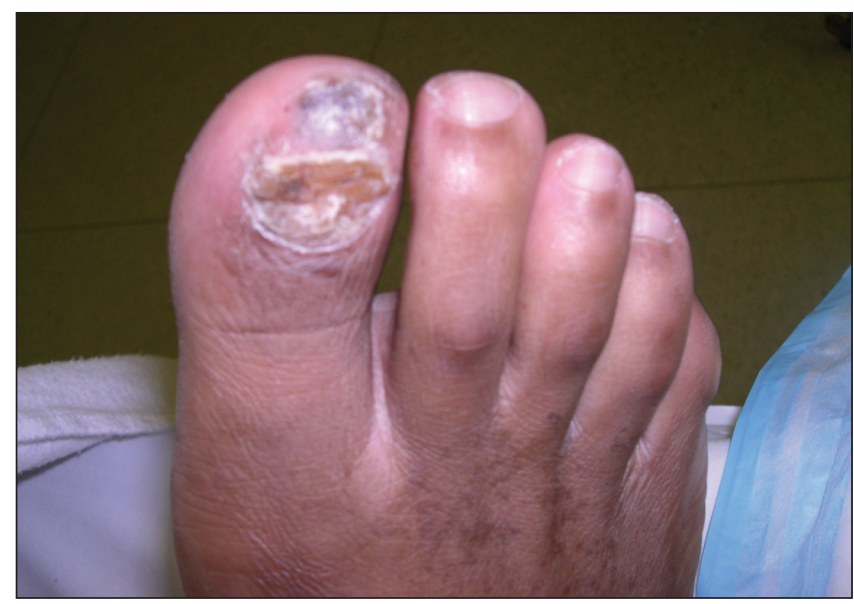

Figure 1) Melanoma of the big toe

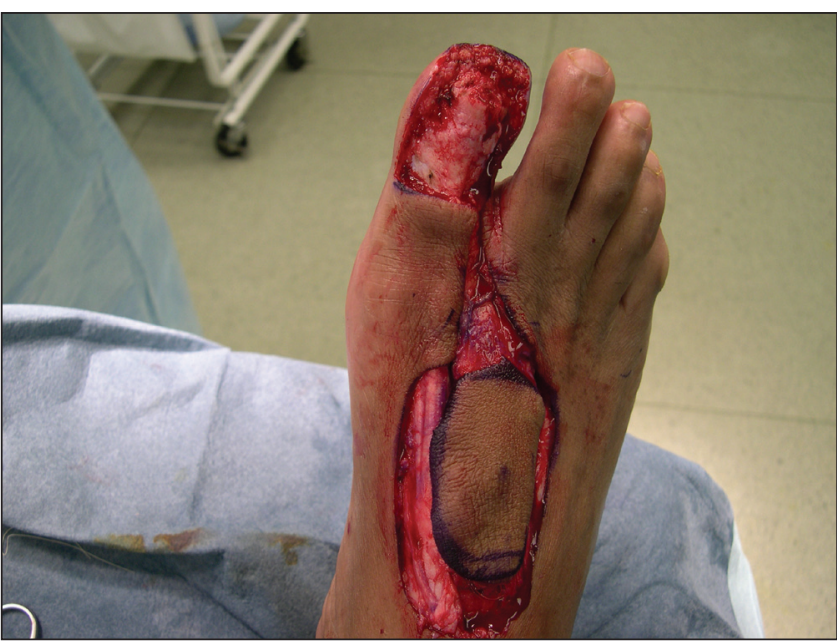

Figure 2) Defect following excision with the flap outlined

Division of Plastic Surgery, Wayne State School of Medicine, Detroit, Michigan, USA.

Correspondence: Dr C Balakrishnan, Division of Plastic Surgery, John Dingell Veterans Affair Medical Center, 4646 John R, Detroit, Michigan 48201, USA 


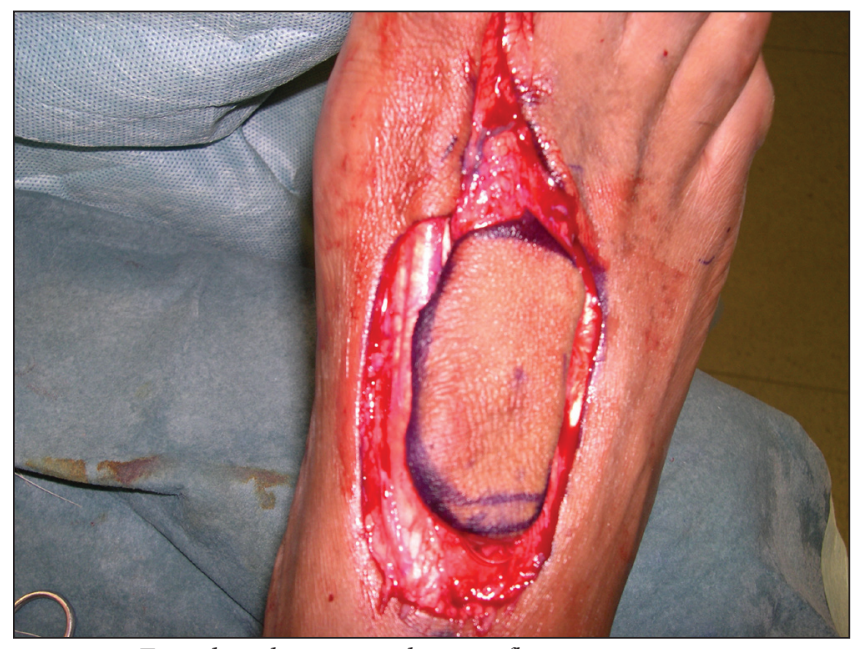

Figure 3) First dorsal metatarsal artery flap

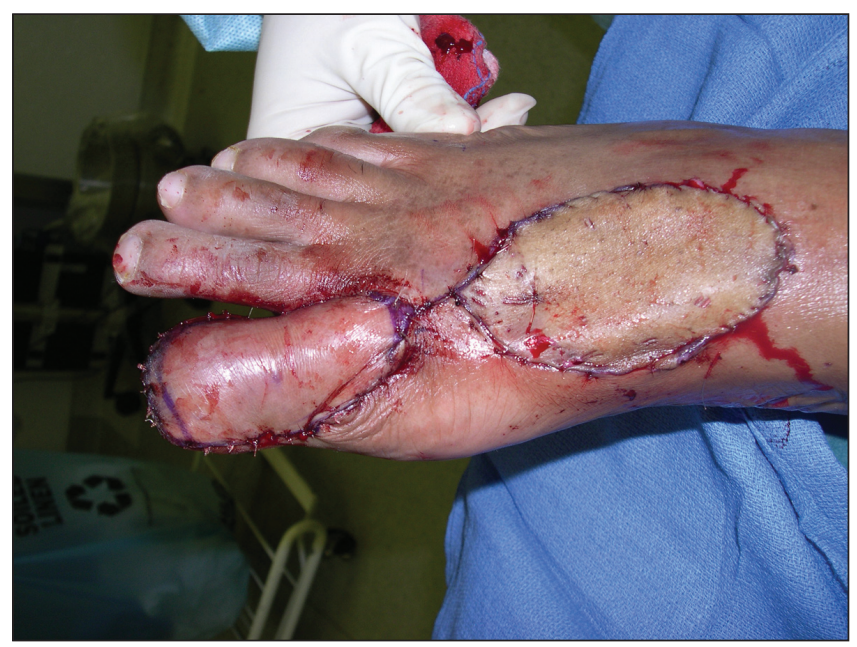

Figure 4) Closure of the defect

provides excess tissue bulk for small defects of the great toe, and free tissue transfers are time consuming and may be associated with higher failure and reoperative rates in patients with comorbities such as diabetes or aging $(1,2)$.

\section{Reversed dorsal metatarsal artery flap}

The dorsalis pedis artery, which is an extension of the anterior tibial artery, supplies the flap. The anterior tibial artery lies lateral to the tibialis anterior tendon and medial to the extensor hallucis longus tendon at the entrance of the extensor retinaculum or the ankle. It courses under the retinaculum and emerges medial to the extensor hallucis longus tendon as the dorsalis pedis artery. The dorsalis pedis artery branches to form the arcuate artery, lateral and medial tarsal arteries, which supply structures beneath the extensor tendons and are not harvested as part of the flap. The artery branches into the first dorsal metatarsal artery and deep perforating branch at the first intermetatarsal space. The perforating branch joins the plantar

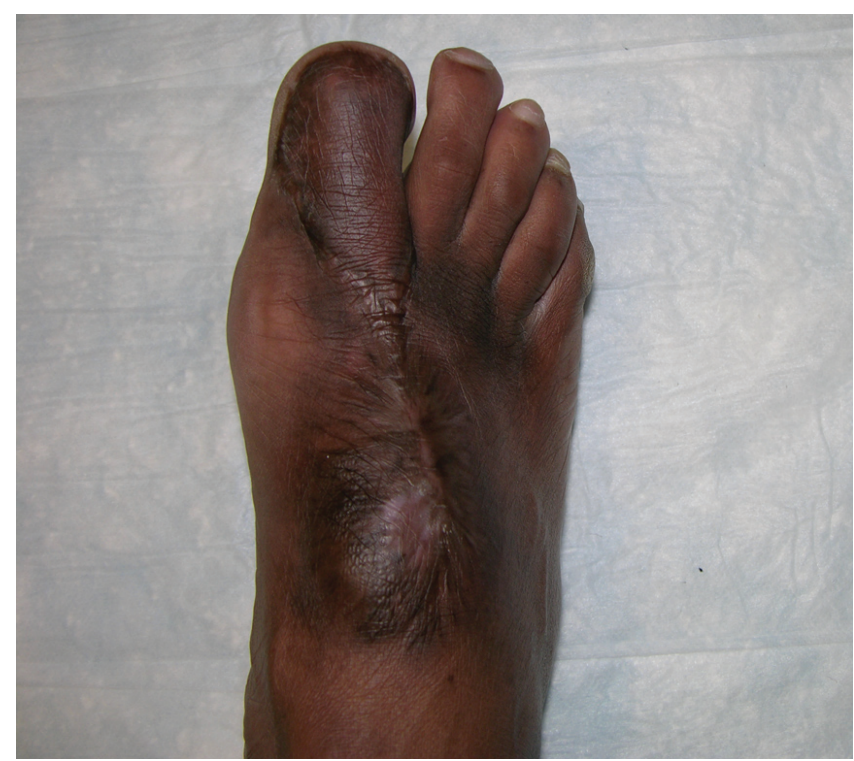

Figure 5) Result at 18 months

lateral tarsal artery in $9.4 \%$ of cases. The critical point, where the first dorsal metatarsal artery (or the first plantar metatarsal artery in cases when the former branched from the latter) was located $10 \mathrm{~mm}$ distal to the tarsal-first metatarsal joint and $5.5 \mathrm{~mm}$ plantar from the dorsal surface of the second metatarsal bone. The medial head of the first dorsal interosseous muscle crossed dorsal to the first dorsal metatarsal artery in $31.2 \%$ of cases. The first dorsal metatarsal artery coursed superficial to the first dorsal interosseous muscle $(59.4 \%)$, was partially embedded with the muscle $(18.8 \%)$, or coursed along the bottom of it or below it (21.9\%). In the latter type, four of seven specimens showed the thin arterial loop. The arterial network in the first interosseous space presented several anatomic variations. The standard pattern (group 1) was most frequent (71.9\%). Other variations (group 2) could be further categorized into four subdivisions according to the pattern of the arterial interconnection (4).

In our patient, following wide excision of the melanoma, a distally based dorsalis pedis island flap based on the first dorsal metatarsal artery was successfully used to treat the defect. This flap has provided him with stable coverage for the use of regular footwear.

\section{REFERENCES}

1. Hayashi A, Maruyama Y. Reverse first dorsal metatarsal artery flap for reconstruction of the distal foot. Ann Plastic Surgery 1993;31:117-22.

2. Wang XI, Quio Q, Burd A, Qi K. Reconstruction of distal foot wounds with reverse first dorsal metatarsal artery flap. Burns 2005;31:1025-28.

3. Man D, Acland R. The micro arterial anatomy of the dorsalis pedis flap and its clinical applications. Plast Reconstr Surg 1980;65:419-30.

4. Lee JH, Dauber W. Anatomic study of doraslis pedis-first dorsal metatarsal artery. Ann Plast Surg 1997;38:50-5. 